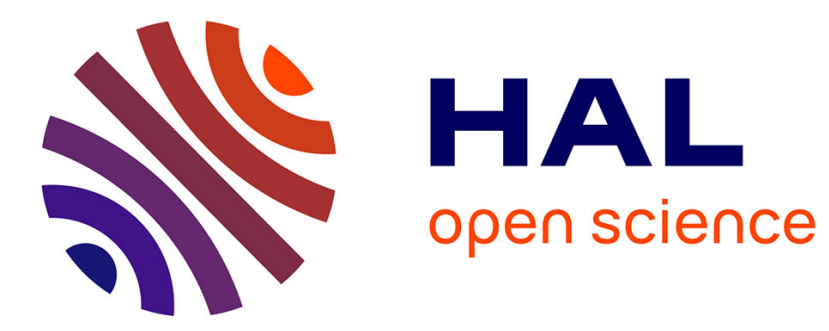

\title{
Logarithmic dependence of the sound velocity in an amorphous metal
}

\author{
G. Bellessa
}

\section{To cite this version:}

G. Bellessa. Logarithmic dependence of the sound velocity in an amorphous metal. Revue de Physique Appliquée, 1977, 12 (5), pp.817-817. 10.1051/rphysap:01977001205081700 . jpa-00244247

\section{HAL Id: jpa-00244247 https://hal.science/jpa-00244247}

Submitted on 1 Jan 1977

HAL is a multi-disciplinary open access archive for the deposit and dissemination of scientific research documents, whether they are published or not. The documents may come from teaching and research institutions in France or abroad, or from public or private research centers.
L'archive ouverte pluridisciplinaire HAL, est destinée au dépôt et à la diffusion de documents scientifiques de niveau recherche, publiés ou non, émanant des établissements d'enseignement et de recherche français ou étrangers, des laboratoires publics ou privés. 


\title{
LOGARITHMIC DEPENDENCE OF THE SOUND VELOCITY IN AN AMORPHOUS METAL (*)
}

\author{
G. BELLESSA
}

Laboratoire de Physique des Solides (**) Université Paris-Sud, 91405-Orsay, France

Résumé. - Les matériaux amorphes isolants ( $\mathrm{Si} \mathrm{O}_{2}$ par exemple) se comportent d'une façon très particulière à basses températures. Il s'agit notamment de la chaleur spécifique qui varie proportionnellement à la température et de la vitesse du son qui varie suivant une loi logarithmique. Ces propriétés sont bien expliquées à l'aide du modèle d'Anderson et al. [1] et Phillips [2] qui suppose l'existence de systèmes à 2 niveaux. Des tentatives récentes d'observation de ces comportements particuliers dans les métaux amorphes ont été infructueuses. Nous reportons ici l'observation de la dépendance logarithmique de la vitesse du son dans NiP au-dessous de $2 \mathrm{~K}$. NiP est un amorphe métallique non magnétique. La vitesse du son est mesurée à $\pm 2 \times 10^{-6}$ près pour des ondes longitudinales et transversales à des fréquences de l'ordre de $100 \mathrm{MHz}$ et des températures à partir de $0,4 \mathrm{~K}$. La dépendance logarithmique de la vitesse est 3 fois plus importante pour les ondes transversales que pour les ondes longitudinales. Cependant l'effet reste toujours sensiblement plus faible que dans les amorphes isolants.

\begin{abstract}
The amorphous materials behave in a particular way at low temperatures. Especially, the specific heat is proportional to the temperature and the sound velocity follows a logarithmic law. These properties are well explained with the model of Anderson et al. [1] and Phillips [2] which assumes the existence of two-level systems. Recent attempts to observe such properties in amorphous metals have not succeeded. We report here, the observation of a logarithmic dependence of the sound velocity in Ni-P below $2 \mathrm{~K}$. Ni-P is a non-magnetic amorphous metal. The sound velocity is measured with an accuracy of $\pm 2 \times 10^{-6}$ for the longitudinal and transverse waves at frequencies around $100 \mathrm{MHz}$ and temperatures down to $0.4 \mathrm{~K}$. The logarithmic dependence of the velocity is $\mathbf{3}$ times larger for the transverse waves than for the longitudinal ones. However the effect remains in the two cases appreciably smaller than in amorphous insulators.
\end{abstract}

(*) This paper will be published in «Le Journal de Physique-Lettres » France.

(**) Laboratoire associé au C. N. R. S.

\section{References}

[1] Anderson., P. W., Halperin, B. and Varma, C., Phil. Mag. 25 (1972) 1.

[2] Phillips W. A., J. Low Temp. Phys. 7 (1972) 351. 